\title{
Causes of the Subprime Crisis and Its Enlightenment to China's Economy
}

\author{
Tianyi Wang
}

\author{
Lawrence Woodmere Academy, New York 11598, United States
}

Email:1091231827@qq.com

\begin{abstract}
The reasons for the subprime mortgage crisis in the United States are involved in this paper. On the surface, it is the result of the Fed's rate adjustment. In fact, there are many more in-depth reasons for the outbreak. In this article, briefly summarizing the development process, the author carefully summarize the realization that the crisis brought by analyzing the causes of its occurrence and the cause of the crisis. The crisis has inspired us to consume rationally, change the economic growth mode, strengthen financial supervision while financial innovation, and guard against risks, especially in the real estate market.
\end{abstract}

Keywords: Causes of Subprime Crisis, China's economic development, rational consumption, financial supervision

\section{INTRODUCTION}

Financial turmoil caused by the U.S. subprime mortgage crisis in early 2007 quickly swept the world. This crisis mainly originated from the burst of the real estate bubble, and the financial innovation chain formed around subprime mortgages further deepened the subprime mortgage crisis. With the possibility of reshaping, it also provides opportunities and challenges for China's development. What are the reasons for the crisis? What are the impacts on the economic development of China?

\subsection{The U.S. Subprime Crisis}

The U.S. subprime crisis is called the subprime mortgage crisis in the U.S. real estate market. When buy high-grade goods, especially houses, Americans mostly pay in instalments using mortgages. In general, Bank of America sets the credit rating of consumers who are able to pay on time as superior and considers consumers' credit rating who are unable to pay on time to be inferior. In general, mortgage lenders do not have or lack sufficient evidence of income or ability to repay or have heavy other debts and "inferior" credit terms. This type of real estate mortgage loan is called a subprime mortgage loan. Compared to mortgage lenders with better credit standing, subprime mortgage lenders typically pay higher interest rates and must adhere to stricter repayment methods in terms of interest rates and repayment methods. To stimulate consumption and the economic growth, the United States has issued a number of mortgage loans to consumers with lower reputes by lowering bank rates since early 2001, allowing people with low incomes and low credit ratings to save their homes. Increasing the level of national well-being in the development of the U.S. economy has played a positive role. However, after the U.S. economy steadily recovered and developed, bank rates rose, and subprime mortgage interest rates on bank loans rose sharply. As a result, these people cannot repay the bank loan and even have to mortgage their property to the bank. To achieve the purpose of diversifying risk, banks will convert them into funds to secure many mortgage assets and then sell them to investors in different countries. If credit is weakened and home prices rise, lenders can take back the defaulter's home and resell it or even make money without loss. However, when credit terms change, especially when home prices start to decline, things are entirely different. It is difficult for buyers to sell their homes or finance them through mortgages. A similar large-scale event leads to a subprime mortgage crisis. [3][5]

\subsection{Causes of the Subprime Crisis}

The outbreak of the subprime mortgage crisis in the United States was not an accidental result of a single factor but multiple effects. 


\subsubsection{Misdirection of national policy}

To boost economic growth, the Federal Reserve has cut interest rates 13 times since 2001. By mid-2004, the U.S. interest rate had been cut to $1 \%$, the lowest level in 46 years. The U.S. economy, boosted by a low-interest rate policy, thrived in the first half of 2004. At this time, in order to curb excessively rapid economic growth, the Fed gradually began to raise interest rates. Since mid2004, the federal rate has increased 17 consecutive times, reaching 5.25\% in August 2007. Federal interest rate adjustments have had two effects. On the one hand, the low-interest rate policy was greatly stimulated. U.S. house prices have skyrocketed due to increased investment in the U.S. real estate market. Combined with the implementation of zero down payment policies by some U.S. lenders, the higher the house price was pushed, the bigger the bubble is. On the other hand, as the interest rate rises, the burden on repayer is increasing. At the same time, a significant number of invested home buyers have significantly reduced their home assets due to falling house prices. Under these two pressures, repayers must give up the property and refuse to pay the loan. Subprime mortgage companies become the direct victims, and investors holding asset-backed bonds become the indirect victims. [6]

\subsubsection{Long-term imbalances in the real economy}

In the past few years, the United States has been advocating the so-called new economic concept, claiming that the world's industrial structure is changing from an industrial type to a service-oriented economy, so that the economic development of the United States ignores the real economy. The development that depends entirely on the service industry is easily affected by external factors, such as resource allocation policies, income levels, and even fashion trends. It is also extremely easy to hit the development of the service industry. At the same time, under the leadership of financial capital, the United States has moved towards economic bubbles. At this time, the United States just realized that this was the result of hollow manufacturing. [1]

\subsubsection{The lack of government supervision (the lack of a certain credit rating system)}

Subprime mortgage loans were an emerging financial innovation product at the time. In the process of its production and development, due to the imperfect government regulatory mechanisms and relevant legal systems, unhealthy competition was common in the development of the subprime mortgage market. Existence makes the crisis finally break out. In this subprime mortgage crisis, the regulatory authorities did not give full play to their responsibilities and functions, coupled with the loose legal environment, making many financial institutions and investors more adept. In addition, due to the lack of a credit rating system in the United States, there have been problems with the code of conduct of credit rating agencies, which misled the market to a certain extent. The lack of a credit rating system has an unshirkable responsibility in the subprime mortgage crisis outbreak.

\subsection{The Enlightenment of Subprime Mortgage Crisis to China's Economic Development}

Since China's commercial banks purchase relatively less U.S. mortgage bonds and the renminbi is not freely convertible, the subprime mortgage crisis that swept Europe and the United States has relatively little impact on China. However, China can still learn some lessons and enlightenments from it.

\subsubsection{Reasonable consumption}

After the reform and opening up, many people in China, while learning advanced foreign technologies and concepts, also paid great attention to imitating developed countries' consumption patterns. Regardless of national conditions and their financial resources, consumption was anxious to integrate with international standards immediately. The economic fable of "the Americold American borrows to buy a house, and the Chinesold Chinese Saves money to buy a house" has aroused the "dream of buying a house" of many Chinese people. "If you have money, you can buy a house with loans" has become a financial fashion. In particular, young people pushed themselves into the "Moonlight Clan team, people who spent all their salary every month," early and became out-and-out "house slaves". Houses are getting bigger and house prices are getting higher and higher, and the "house slaves" team is also expanding day by day.

In fact, even in affluent America, not everyone takes a loan to buy a private house. Many people save money to buy a house. Even if they save money, they do not buy a house but rent a house. According to statistics, the ownership rate of urban housing property rights in the United States is 68\%, and that in the United Kingdom is $56 \%$. The standard housing consumption ratio is that $30 \%$ of people buy a house and $70 \%$ live in a rented house, while the housing ownership rate in China is as high as $82 \%$. Therefore, we must learn lessons and consume reasonably, and we must not blindly follow the trend and become "house slaves." Instead, it is easy to repeat the mistakes of American "house slaves".

\subsubsection{Establish an effective supervision system}

In this U.S. subprime mortgage crisis, it can be seen that there are regulatory deficiencies in many links in the U.S. financial system. This is an essential warning to Chinese financial regulators. In the face of the new 
situation of financial globalization and liberalization, while expanding financial opening, regulators must stay close to the market, keep abreast of the market pulse. Also, they should formulate common regulatory standards, common regulatory frameworks, and common risks through international cooperationdisposal methods to deal with possible financial turmoil. [2]

\subsubsection{Increase the pace of independent innovation}

In this subprime mortgage crisis, Germany has maintained a low unemployment rate and its economy has grown as a major manufacturing country. However, China, which possesses a large amount of manufacturing, has not been able to survive alone. The fundamental reason is that the per capita level of China's manufacturing output is far behind the level of technological development in developed countries. The contradiction between the organizational structure of manufacturing enterprises and the low industrial concentration is very prominent, and there is still a large gap in management level. The subprime mortgage crisis has stimulated the acceleration of technological progress and innovation, and developed countries have accelerated the adjustment of their strategies for technological and industrial development. China's industry is at the low end of the international industrial chain. If it fails to grasp the trend and seize the opportunity, it will widen the gap with developed countries. China has been at the opposite end of the manufacturing industry for a long time, and exports depend on quantity. Therefore, workers in the manufacturing industry generally have low knowledge and education levels and low incomes, making it difficult for college graduates to find jobs. Therefore, the issue of industrial upgrading is also related to the increase in employment rate and income level.

\subsubsection{The subprime mortgage crisis is a wake- up call for China's mortgage market}

There is no market that only rises and does not fall. The U.S. housing market is a vivid example. For China, the overheating property market is an indisputable fact, but there are still people who believe the "myth" that housing prices only rise but never fall. Some financial institutions have also deliberately staged "lost" in the face of high-profit margins, ignoring risks in good faith, and have launched various methods to attract people to borrow to buy houses. For example, the "revolving loan" business allows people to mortgage commercial housing to the bank to obtain a certain amount of loan. In this way, the more real estate the borrower buys, the more loan line he can get, so it is highly sought after by real estate speculators. In recent years, real estate prices in China's large and medium-sized cities have been rising at an alarming rate. Although there has not been a large-scale loan default phenomenon, the rising inflation rate has forced the central bank to raise interest rates, which has led to many real estate speculators cannot pay interest and breach the contract.

The United States' real estate market has experienced an eight-year boom, prices have only risen by $50 \%$, and people with subprime credit accounted for only $12 \%$ to $13 \%$ of the entire market. A relatively sound financial regulatory system and legal system can hardly avoid a financial crisis. As far as the current situation of China's real estate mortgage market is concerned, not only is there no credit rating for buyers, but it is also far inferior to the United States in terms of legal system arrangements, financial systems, and regulatory systems. In addition, the real estate market prices in some cities have risen in recent years. Soon, the hidden dangers of financial risks always exist. Therefore, the Chinese banking system should speed up the essential work and grasp the loan risk, credit status, and other information promptly. The central bank and other supervisory departments should also strictly supervise and try to resolve the crisis in the bud.

Due to its relative independence from the international market, the safer Chinese real estate market may be more popular with foreign capital, and the influx of foreign capital will further boost housing prices. In this regard, relevant policy-making departments should also be fully prepared. [4]

\section{CONCLUSION}

The global economic crisis triggered by the subprime mortgage crisis in the United States once again shows that the current economic globalization has developed to the extent that it is like "the Domino Effect". As the world's largest developing country and the main exporter of products, any fluctuations in the world will affect China's economic development. While paying close attention to international developments, China should also learn from the experience and lessons of other countries to avoid repeating the same mistakes.

\section{ACKNOWLEDGMENT}

Firstly, I would like to show my deepest gratitude to my teacher and professor, who have provided me with valuable guidance in every stage of the writing of this thesis. In addition, I would like to thank all my friends for their encouragement and support. Without all their enlightening instruction and impressive kindness, I could not have completed my thesis.

\section{REFERENCES}

[1] Xie, Mali, Jun Yao. "The Enlightenment of Subprime Mortgage Crisis to China's Economy." Market Modernization 689 (2012): 191. 
[2] Li, Yue. "The Impact of the US Subprime Mortgage Crisis and Its Enlightenment to China's Economy." Journal of Changchun Normal University (Natural Science) Vol. 29 No. 5 (2010): 140.

[3] Jia, Weiwei. "Analysis on the Causes of American Subprime Mortgage Crisis." Market Modernization 569 (2009): 338.

[4] Liu, Yingkui. "An Analysis of the Causes of the US Subprime Mortgage Crisis and Its Enlightenment to China's Economic Development." Journal of BUPT (Social Sciences Edition) Vol. 10 No. 3 (2008): 34.

[5] Shi, Chenzhou. "An In-depth Analysis of the Causes of the Subprime Mortgage Crisis." Huabei Finance 2 (2009): 33.

[6] Ouyang, Yuanze. "Analysis of the causes of the American subprime mortgage crisis and its enlightenment to China." Foreign Investment in China 275 (2012): 50. 